\title{
One-step Growth Gurves for Inclusion Blennorrhoea Virus in HeLa Cell Monolayers
}

\author{
By G. FURNESS AND ELIZABETH F. FRASER \\ Medical Research Council, Trachoma Research Unit, The Lister Institute of \\ Preventive Medicine, Chelsea Bridge Rd, London, S.W. 1
}

(Received 20 June 1961)

\begin{abstract}
SUMMARY
When incubated in tissue-culture medium, inclusion blennorrhoea virus lost infectivity for $\mathrm{HeLa}$ cells at $37^{\circ}$ but not at $30^{\circ}$. The rate of adsorption of virus to HeLa cell monolayers was dependent on temperature and on the volume of the inoculum. When the volume of medium was minimal, the virus was adsorbed before a detectable proportion was inactivated. Adsorption was complete after $7-8$ hr. at $30^{\circ}$ and $5-6$ hr. at $3 \pi^{\circ}$.

At $30^{\circ}$ the intracellular virus went into eclipse and maturation was retarded. When the temperature was raised to $37^{\circ}$ maturation was rapid so that, for practical purposes, replication was synchronized during this period. In singly infected HcLa cells, at $37^{\circ}$ infective virus was not detected for $22-23 \mathrm{hr}$, after which the progeny increased exponentially until at 34-38 hr. 35-60 infectious particles/ infected cell were formed. The total number of particles/inclusion seen in Giemsastained preparations exceeded the number of infectious units/inclusion.

After $42-48 \mathrm{hr}$. infective virus was found in the supernatant and the number of intracellular infectious units began to decrease. Unlike vaccinia, another large virus, the virus progeny did not directly infect adjacent cells.
\end{abstract}

\section{INTRODUCTION}

The technique for assaying inclusion blennorrhoca and trachoma viruses in HeLa cell monolayers described by Furness, Graham \& Reeve (1960), slightly modified, was used to study the adsorption and intracellular growth of inclusion blennorrhoea virus in HeLa cell monolayers.

\section{METHODS}

Virus. The LB1 strain of inclusion blennorrhoea virus (Jones, Collier \& Smith, 1959) was grown in HeLa cell monolayers in $250 \mathrm{ml}$. Pyrex feeding bottles (Furness et al. 1960). Suspensions were prepared by resuspending monolayers in $10 \mathrm{ml}$. medium 68- $72 \mathrm{hr}$. after infection, transferring them to a $50 \mathrm{ml}$. centrifuge tube cooled in ice water and releasing the virus by treatment for $4 \mathrm{~min}$. with ultrasonic vibrations. For this purpose a stainless-stecl probe of an M.S.E.-Mullard ultrasonic disintegrator with a power output of $60 \mathrm{~W}$. at a frequency of $20 \mathrm{kc}$. $/ \mathrm{sec}$. was inserted in the cell suspension. The suspensions contained $2 \cdot 5-5 \times 10^{7}$ infectious units/ml.

HeLa cell monolayers. These were grown in Hank's balanced saline solution 
containing $\mathbf{0 . 5} \%(\mathrm{w} / \mathrm{v})$ lactalbumin hydrolysate, $10 \%(\mathrm{v} / \mathrm{v})$ human serum, $5 \%(\mathrm{v} / \mathrm{v})$ calf serum and $100 \mu \mathrm{g} . / \mathrm{ml}$. streptomycin; the sera were inactivated by heating at $56^{\circ}$ for $1 \mathrm{hr}$. HeLa cell monolayers grown on coverslips in Leighton tubes were used in all quantitative experiments (Furness et al. 1960).

Virus assay. The medium covering the HeLa cell monolayers was replaced with $0.25 \mathrm{ml}$. fresh medium and infected with $0.1 \mathrm{ml}$. of a suitable dilution of virus. The virus was allowed to adsorb for at least 6-7 hr. at $37^{\circ}$. Thereafter $1.5 \mathrm{ml}$. medium was added to each monolayer. After incubation for 62-66 hr., the coverslips were removed, stained with Giemsa and the inclusions in thirty fields counted at a magnification of $\times 240$ (Furness et al. (1960). Cultures were incubated at $37^{\circ}$ unless otherwise stated.

One-step growth curves. Monolayers covered with $0.25 \mathrm{ml}$. medium were infected with $0.1 \mathrm{ml}$. of a virus dilution capable of infecting between 300 and 800 of the cells in an area of thirty fields after adsorption for $2 \mathrm{hr}$. at $30^{\circ}$.

After the virus had been allowed to adsorb to the monolayers for $2 \mathrm{hr}$. at $30^{\circ}$ unadsorbed virus was removed by washing with phosphate buffered saline (Dulbecco \& Vogt, 1954) at $30^{\circ}$. To count the number of cells infected, five monolayers were covered with $2 \mathrm{ml}$. medium and the inclusions counted after incubation for $68-72 \mathrm{hr}$. at $37^{\circ}$. The remaining monolayers were covered with $1 \mathrm{ml}$. medium and incubated at $37^{\circ}$ to allow maturation of the virus. Released and intracellular inclusion forming units were determined during replication as follows. At intervals, four monolayers were chosen at random and the supernatants pooled and titrated to obtain the number of infectious units released from the cells. The cells themselves were resuspended in a total of $4 \mathrm{ml}$. medium, disintegrated with ultrasonic vibrations and assayed to determine the number of intracellular infectious units.

\section{RESULTS}

The effect of temperature on the viability of inclusion blennorrhoea virus. To assess the rate of inactivation of virus at $37^{\circ}, 4 \mathrm{ml}$. of a suitable dilution of virus prepared in medium at $\mathrm{pH} 6 \cdot 7-7 \cdot 1$ were incubated in $\frac{1}{4} \mathrm{oz}$. screw-capped bottles in a waterbath. At intervals $\mathbf{0} \cdot \mathbf{1} \mathrm{ml}$. samples were titrated in HeLa cell monolayers covered with $1 \mathrm{ml}$. medium. No virus was inactivated in $8-10 \mathrm{hr}$. at $30^{\circ}$, whereas over $80 \%$ of the virus was killed in $6 \mathrm{hr}$. at $37^{\circ}$. The virus was not protected by increasing the serum content of the medium from 15 to $45 \%$ (Table 1 ).

Adsorption of virus to HeLa cell monolayers. To determine the degree of inactivation during the adsorption period, monolayers covered with $1 \mathrm{ml}$. medium were

Table 1. The loss of infectivity of inclusion blennorrhoea virus for HeLa cells at $37^{\circ}$

$\begin{array}{cc}\begin{array}{c}\text { Suspending } \\ \text { medium. } \\ \text { Culture medium } \\ \text { containing } \\ \text { (\% serum) }\end{array} & \begin{array}{c}\text { Inoculum } \\ (\text { no. } / \mathrm{ml} .)\end{array} \\ 15 & 2.8 \times 10^{6} \\ 15 & 6.7 \times 10^{6} \\ 15 & 3.0 \times 10^{6} \\ 30 & 3 \cdot 0 \times 10^{6} \\ 45 & 3.0 \times 10^{6}\end{array}$

$\overbrace{2 \mathrm{hr} .}^{\begin{array}{c}\% \text { infectious units surviving after } \\ \text { incubation at } 37^{\circ} \text { for }\end{array}} \begin{array}{ccc}4 \mathrm{hr} & 6 \mathrm{hr} . \\ 86 & 28 & 14 \\ 40 & 33 & 21 \\ 48 & 21 & 10 \\ 50 & 24 & 8 \\ 44 & 22 & 7\end{array}$


inoculated with $0.1 \mathrm{ml}$. of a suitable dilution of virus and incubated at $30^{\circ}$ or $37^{\circ}$ to allow the virus to adsorb to the cells. At intervals, four monolayers were freed from unadsorbed virus by washing with phosphate buffered saline, covered with $2 \mathrm{ml}$. medium and incubated for 68-72 hr. at $37^{\circ}$ to enable adsorbed particles which were still infectious to form inclusions. Compared with the infectious units adsorbed in $8 \mathrm{hr}$. at $30^{\circ}$, only half the virus formed inclusions at $37^{\circ}$ indicating that some infectious units were inactivated. The method of titration of inclusion blennorrhoea virus in HeLa cell monolayers (Furness et al. 1960) did not therefore determine the total number of infectious units in the original suspension.

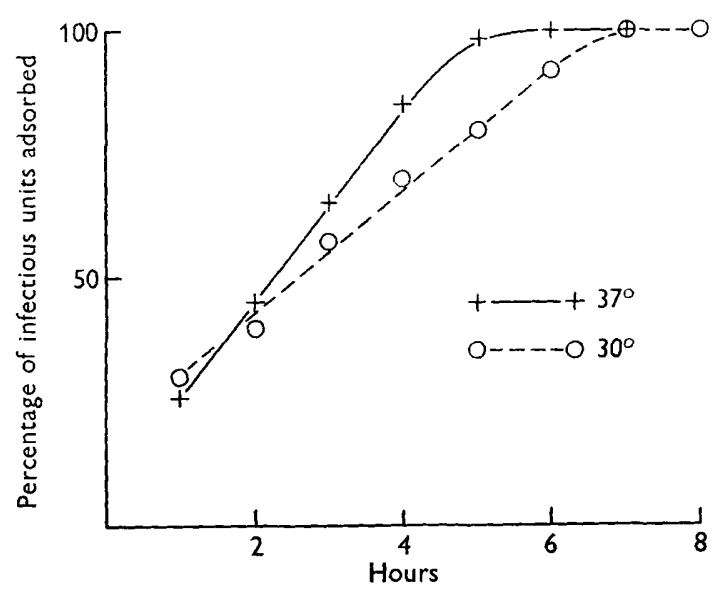

Fig. 1. The rate of adsorption of inclusion blennorrhoea virus by HeLa cells at $30^{\circ}$ and $37^{\circ}$.

Since the efficiency of adsorption of polio-virus to cell monolayers is increased by decreasing the volume of the supernatant fluid (McLaren, Holland \& Syverton, 1959 ; Furness, 1961), the experiment was repeated with $0.25 \mathrm{ml}$. medium; the total volume after inoculation thus being only $0.35 \mathrm{ml}$. This modification increased the efficiency of adsorption. Similar number of inclusions were formed after adsorption for $7-8 \mathrm{hr}$. at $30^{\circ}$ and 5-6 hr. at $37^{\circ}$ (Fig. 1), indicating that the infectious units were adsorbed from this volume before significant inactivation occurred. These results do not appear consistent with the finding that over $80 \%$ of the virus was inactivated in $6 \mathrm{hr}$. at $37^{\circ}$ (Table 1 ). In the two experiments, the virus was assayed under different conditions which may explain this inconsistency.

To verify that diminution of the volume of supernatant fluid did not affect the accuracy of titrations, the results of four assays were analysed statistically (Furness et al. 1960). The random distribution of the inclusions and the accuracy of the titrations were not altered, the standard error being within $\pm 10 \%$.

The multiplication of inclusion blennorrhoea virus in HeLa cells. Three one-step growth curves for inclusion blennorrhoea virus are summarized in Fig. 2. In these experiments respectively $1.2,1.8$ and $4.8 \%$ of the cells in the monolayers were infected. The results therefore reflect the behaviour of singly infected cells. After adsorption at $30^{\circ}$ for $2 \mathrm{hr}$., at least $88 \%$ of the adsorbed virus was irrecoverable, the remainder being released as infective virus on disintegrating the cells. Thereafter, the temperature was raised to $37^{\circ}$ to allow normal maturation of the virus. Less 
than $1 \%$ of the adsorbed virus was infective $4 \mathrm{hr}$. later. With this virus-cell system, the period during which virtually no virus was recoverable is termed the eclipse stage and is considered to end when each infected cell contains an average of one

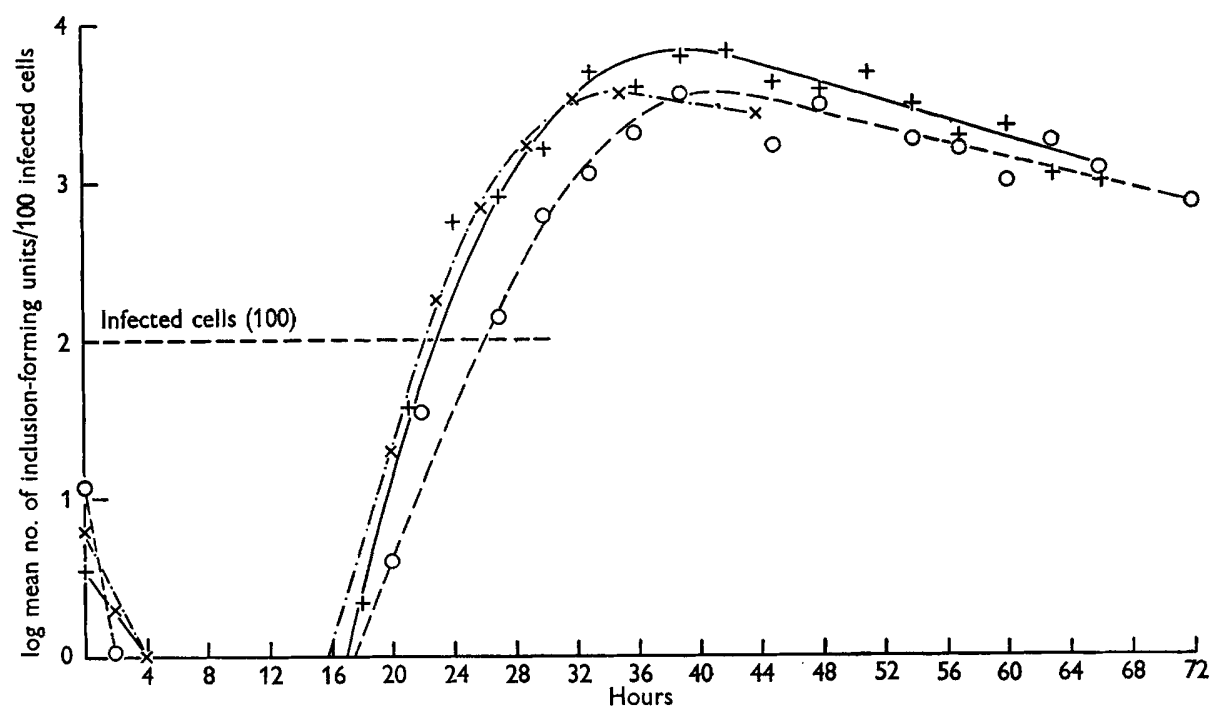

Fig. 2. One-step growth curves of 3 experiments with inclusion blennorrhoea virus in HeLa cell monolayers at $37^{\circ}$.

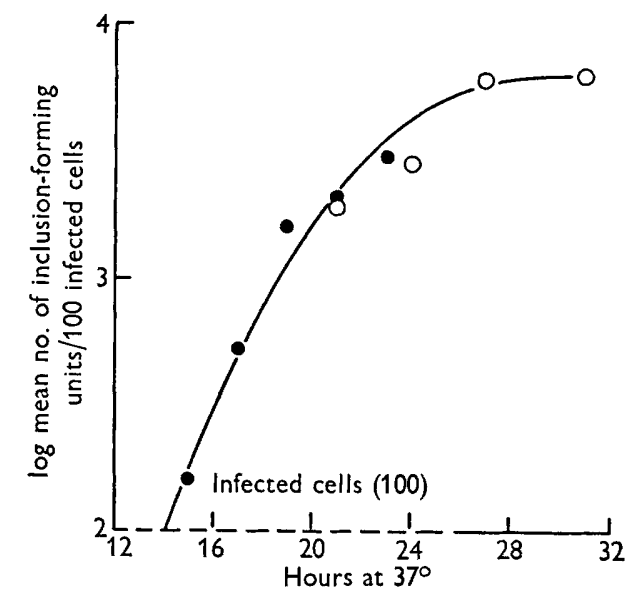

Fig. 3. Effect of pre-incubation for $24 \mathrm{hr}$. at $30^{\circ}$ on one-step growth curve of inclusion blennorrhoea virus in $\mathrm{HeLa}$ cell monolayers at $37^{\circ}$. For convenience, this experiment was done in two parts ( $O$ and $O$ ).

infectious unit; in these experiments it lasted $22-23 \mathrm{hr}$. Once replication commenced, the intracellular infectious units increased exponentially until a peak was reached at 34-38 hr. with a yield of 35-60 infectious units/inclusion. From 42-48 hr. until the experiments were ended, a quantity of virus equivalent to $1-2 \%$ of the intracellular virus was present in the supernatant medium at each assay. Concomitantly, the number of intracellular infectious units progressively decreased. 
From 18 to $52 \mathrm{hr}$. sample monolayers were stained by Giemsa. Although the visible particles in the inclusions could not be counted accurately, they obviously exceeded the numbers estimated by infectivity titrations.

The eclipse phase of inclusion blennorrhoea virus at $30^{\circ}$. Inclusions could not be seen in infected monolayers after 24 and $48 \mathrm{hr}$. incubation at $30^{\circ}$ suggesting that the maturation of inclusion blennorrhoea virus was affected. To ascertain whether the virus replicated during incubation at $30^{\circ}$, the technique for obtaining one-step growth curves was modified after adsorption at $30^{\circ}$, by continuing incubation of the washed monolayers at this temperature for a further $24 \mathrm{hr}$. Thercafter the temperature was raised to $37^{\circ}$ and the intracellular infectious units assayed periodically. The number of infected cells did not decrease as a result of incubation at $30^{\circ}$ indicating that the intracellular virus remained viable. The curve itself (Fig. 3 ) ran parallel to those obtained previously and the yield of sixty infectious units/inclusion was not affected (Fig. 2). After 24 hr. at $30^{\circ}$, the incubation period required for the production of infectious units at $37^{\circ}$ was reduced by about $8 \mathrm{hr}$. (Fig. 3). Thus inclusion blennorrhoea virus in eclipse continued to mature at $30^{\circ}$ at only one-third of the rate at $37^{\circ}$.

\section{DISCUSSION}

The replication of inclusion blennorrhoea virus in HeLa cells was studied by a technique similar to that reported previously for vaccinia virus (Furness \& Youngner, 1959 $a, b$ ) and poliovirus (Furness, 1961) in which multiplication in singly infected cells is synchronized by adsorbing virus at temperatures which retard the rate of replication. The rate of maturation of inclusion blennorrhoea virus at $30^{\circ}$ was one-third that at $37^{\circ}$; it was therefore negligible during the $2 \mathrm{hr}$. adsorption period and growth of the virus was virtually synchronized.

Our results indicated that this agent behaved like other animal viruses in that it had a stage during which infective virus could not be demonstrated. Meningopneumonitis virus of the psittacosis group was grown in tissue cultures of allantoic membranes (Girardi, Allen \& Sigel, 1952) and L cells (Higashi, Notake \& Fukada, 1959) with similar results. After adsorption to the cells, inclusion blennorrhoea virus and meningo-pneumonitis virus were not detected for 20-23 hr. Thereafter they increased exponentially until a peak was reached at $34-38 \mathrm{hr}$. Both viruses were heat labile at $37^{\circ}$ and $35^{\circ}$, respectively. Heat inactivation of inclusion blennorrhoea virus during adsorption was obviated by our techniques. No evidence, however, was presented to exclude this possibility during adsorption of meningo-pneumonitis virus so it is possible that the assays of this virus underestimated the total number of infectious units. Nor was the release of meningopneumonitis virus from infected cells reported. Infective inclusion blennorrhoea virus was found in the supernatant medium suggesting spontaneous relcase from the inclusions. Since inclusion blennorrhoea virus is labile at $37^{\circ}$ the unexpectedly small amount of infective virus found in the supernatant medium could be accounted for by heat inactivation and adsorption to the monolayer.

There was no evidence of cell to cell spread of virus as occurred in similar experiments with vaccinia virus in tissue culture (Furness \& Youngner, 1959a,b).

We wish to thank Miss Margaret Ham for her excellent technical assistance. 


\section{REFERENCES}

Dulbecco, R. \& Vogt, M. (1954). Plaque formation and isolation of pure lines with poliomyelitis virus. J. exp. Med. 99, 167.

Furness, G. (1961). The effect of environment on the replication of poliovirus in monkey kidney cells. J. gen. Microbiol. 25, 421.

Furness, G., Graham, D. M. \& Reeve, P. (1960). The titration of trachoma and inclusion blennorrhoea viruses in cell cultures. J. gen. Microbiol. 23, 613.

Furness, G. \& Youngner, J. S. $(1959 a)$. The replication of vaccinia virus in monkey kidney cell cultures. J. gen. Microbiol. 21, viii.

Furness, G. \& Youngner, J. S. (1959b). One-step growth curves for vaccinia virus in cultures of monkey kidney cells. Virology, 9, 386.

Girardi, A. J., Allen, E. G. \& Sigel, M. M. (1952). Studies on the Psittacosis-Lymphogranuloma group. II. A non-infectious phase in virus development following adsorption to host tissue. J. exp. Med. 94, 233.

Higashi, N., Notake, K. \& Fukada, T. (1959). Growth characteristics of the meningo pneumonitis virus in strain L cells. Ann. Rep. Inst. Virus Res., Kyoto Univ. $2,23$.

Jones, B. R., Collier, L. H. \& Smith, C. H. (1959). Isolation of virus from inclusion blennorhoea. Lancet, i, 902.

Mclaren, L. C., Holland, J. J. \& Syverton, J. T. (1959). The mammalian cell-virus relationship. I. Attachment of poliovirus to cultivated cells of primate and non primate origin. J. exp. Med. 109, 475. 